\title{
Peng's Proposal For Special Religious Zones in China
}

\author{
Michael P. Ferber \\ Associate Professor of Geography and Environmental Studies, The King's University College, 912550 St. Edmonton, AB T6B 2H3 \\ *Corresponding author: michael.ferber@kingsu.ca
}

Copyright (C) 2013 Horizon Research Publishing All rights reserved.

\begin{abstract}
This article discusses the potential of special religious zones to enhance social harmony in China and serve as 'useful opium'. Liu Peng has suggested that special religious zones could be created in the same way that special economic zones helped to open China to free economic markets.These special religious zones would encompass a geographical region in which the country's typical or national laws would be modified as a type of social experiment in religious freedom. Two particular areas special religious zones could enhance social harmony include solutions to social crises caused by regional migration and to China's growing environmental crisis.
\end{abstract}

Keywords Religion, China, Religious Zones, Christianity

\section{Introduction}

Dr. Liu Peng, 1 Director of the Beijing Pu Shi Institute for Social Sciences, has proposed a fascinating geographic solution to the problem of religious freedom, and in particular rapid house church growth, in China.Peng suggests that special religious zones could be created in the same way that special economic zones helped to open China to free economic markets. These special religious zones would encompass a geographical region in which the country's typical or national laws would be modified as a type of social experiment in religious freedom.

The creation of special economic zones in 1980 involved a loosening of economic domination by the central government, something which was previously a hallmark of the Chinese economy. The cities of Shenzhen, Zhuhai, Shantou and Xienan in the Guangdong and Fuijian provinces were provided with lower tax rates and the capacity to receive foreign investment without clearance from Beijing. Their rapid success, in contrast to the rest of the Chinese economy, led to fourteen more cities being pronounced as special economic zones in 1984. According to T.K. Bhaumik, this process of reform was particularly special because it did not involve foreign consultation and was strictly a Chinese

1 Dr. Peng also serves the Institute of American Studies in the Chinese Academy of Social Sciences solution to a Chinese problem. "China did not borrow any ideas from foreign experts who could have instantly provided a package, along with a roadmap and a timetable for the same. China's new economic policies were not import-oriented, but were derived from internal debates and the experiences gained."2

Likewise, Peng's proposal for Special Religious Zones would also be a Chinese solution to a Chinese problem. Though Peng has not yet published anything in English about this idea, he has shared it with numerous scholars and members of the Communist Party in China ${ }^{3}$. He believes that a resolution lies in the implementation of the rule of law through a new understanding of the religious management system. Peng argues that whenever public policy is made it should always regulate interests, balance liberty with order and rights with obligations. He believes the problem of house churches is not an isolated one, but touches on several other issues, both domestic and international. Because China is still without a properly implemented, nationwide system of religious legislation, consideration needs to be paid to the difficulty and length of time it would involve to create one. His suggestion is that several localities could be selected to experiment in implementing a progressive religious administrative system, especially to allow religions to enter the field of social service. He suggests that Wenzho, Xiamen, Shijiazhuang, Zhengzho, Lanzhou and Kunming be selected as experimental Special Religious Zones.Peng hopes to see a legal system in which internal religious questions, including the Protestant House Churches, cause the religions themselves to become positive factors in the promotion of social development.Peng'sgeographic proposal could provide for gradual religious freedom in the country using an indigenous model that has already proven fruitful in economic terms.

\section{Christianity in China}

The traditional Marxist, Leninist view has been to see religion as the opiate of the people. Yet, according to Fallman "these phrases are rarely seen in documents or heard

2 T.K. Bhaurmik. Old China's New Economy: The Conquest of a Billion Baupers. (New York: Sage, 2009), 102.

Information from this section was shared by Liu Peng in person with the author. 
in speeches in China today. They have been replaced by a utilitarian view that since religion continues to exist then it should be useful for society and party." 4 Rather than religion being a socially destructive drug, it is seen to be useful when it helps to promote a harmonious society.

Christianity is exploding in China such that some have compared it to America's great awakening, 5 rendering the metaphor to opium somewhat relative.

"What is unfolding in China cannot be oversimplified as solely a "revival" of religion; instead, it is, in fact, a multidimensional change occurring in the context of modernization, a change spreading to both the material and consciousness domains. In this context, people who had been convinced atheists or simply uninterested in religion are increasingly looking to religion for answers about who they are, what their existence means, and even for relief from ordinary suffering. In short, they are becoming occupied with what Tillich calls "ultimate concerns." 6

Though it is very difficult to get a head count of Christians in China 7, there are certainly more today than there were when foreign missionaries were active. Chinese church historian Lian Xi does not dispute Micklethwait and Wooldrige's 8 claim that China could be the largest Christian nation by the year 20509. In light of Christianity's growth, it is not surprising that issues of freedom of religion and the rule of law have been on the front pages of western newspapers.

The primary church in the headlines is the Shouwang congregation in Beijing, which grew to over 1,000 members. The name Shouwang means "stand watch," and the church's leadership seeks to be a "city on a hill" (Yala. 2012). Most house churches multiply when they grow beyond the capacity to be held in a home, and when Pastor Jin Tinming of Shouwang started his house church in 1993 he followed this model. By 2005 there were over a dozen fellowship groups that had multiplied from the original, and Pastor Tinming decided to conglomerate these groups into one congregation by meeting together in a large office building for weekly services (Yang, F. 2011). Then in 2006 the church attempted to register with the government as an independent church, despite not wanting to join the TSPM. On April 10 of 2011, 169 worshippers from Shouwang were detained after a church assembly that occurred in a public park. (Yu, 2011).

In response to governmental treatment of this

4 FrederikFallman, "Useful Opium? Adapted religion and harmony in contemporary China."Journal of Contemporary China.19:67. (2009), 949-969.

5 Ian. Johnson. China Gets Religion.New York Review of Books. (2011). December 22, 2011.

6 XiahengXie. "Religion and Modernity in China: Who Is Joining the Three-Self Church and Why”. Journal of Church and State. 52:1. (2010), 74.

7 Tony Lambert. "Counting Christians in China: A Cautionary Report."International Bulletin of Missionary Research.27:1. (2003), 6-10. 8John Micklewait and Adrian Woolridge.God is Back: How the Global Revival of Faith is Changing the World. (New York: Penguin Press, 2009).

9LianXi. "Beyond Missions?Cultural Christians and Political Dissent in Contemporary China". Paper delivered at the Changing Terrains of American Protestant Missions Conference. Duke Divinity School. March 24, 2011. congregation a group of pastors from various house churches petitioned the government demanding respect for the constitutional right to freedom of religion in China. The petition sought to initiate a probe to investigate the shutdown of Shouwang. In response to the petition, the government stated it singled out Shouwang for, "engaging in illegal gatherings and harming social order," insisting that no religious freedoms had been curtailed. (AFP, 2011) The government further stated, "while enjoying their freedom, citizens must respect their legal rights and obligations and cannot harm the public interest."

According to the State Administration for Religious Affairs (SARA), the declared purpose of China's policy to protect freedom of religious belief is, "to unite all people, regardless of their faith or lack of faith in religions, to better exert their will and energy towards the common goal of building up a powerful modern socialist nation."10 So long as religious adherents remain good citizens of China most in the CCP (Chinese Communist Party) are indifferent. However, religionists can become a cause of concern among government officials if they have close political connections with foreign nations. As one Chinese Christian puts it, "religion has been exploited by colonialists and imperialists in their aggression against China" 11. Additionally, Peng himself confirms that most of the peasant uprisings in China's history have been initiated under the banner of religion. 12 Hence, centuries of government mistrust over foreign religious influence and the desire of Chinese Christians for an indigenous church cause "foreign" Christianity to remain suspect. 13

Like drug enforcement in the United States, the assumption that increased religious regulation will lead to a reduction of religion has proven to be false. What has developed in China is, according to Yang, a "triple market economy" 14 with a red market of legal religions, a black market of illegal religions and a grey market of religions with ambiguous legal status. Situations like Shouwang are likely to increase unless China finds a way to loosen its grip on religious freedom. Some argue the problem lies in China's application of the rule of law, a topic already covered at length in other chapters of this volume. According to Article 36 of the Chinese constitution, there has been a guarantee of freedom of religion in China since the end of the cultural revolution.Article 36 states, "no state organ, public organization or individual may compel citizens to believe in, or not to believe in any religion." 15 However, religion in China can stillbe interpreted by the state as a form of spiritual

10Liu Peng. "Religious Legislation in China: Historical Evolution and Recent Developments." Religious Studies Review. 1:1. (2007), 63.

11Bishop K. Ting."A Call for Clarity: Fourteen Points From Christians In The People's Republic of China to Christians Abroad." China and Ourselves. 24:1. (1981), 217.

12Liu Peng. Religion as a Factor in Sino-U.S. Relations. The Review of Faith and International Affairs. 6:2(2008), 61-66.

13 Thomas DuBois. "Religion and the Chinese State: Three crises and a solution.".Australian Journal of International Affairs.64:3. (2010), 344-358.

14Fenggang Yang. "The Red, Black and Gray Markets of Religion in China." Sociological Quarterly.47 (2006), 93-122.

15 John Bryan Starr. Understanding China (3rd edition). (2010), 254 
opium with the capacity to disrupt social harmony and loyalty to China. Here the classic insider / outsider problem in religion rears its ugly head16. The government has the authority to prevent religion from disrupting the public order and, in light of the western missionary history of Christianity in China, Article 36 makes clear that "religious affairs are not subject to any foreign domination.

Even within the church in China there is division regarding the state. Bishop Ding Guangxun uses the term "cultural Christians" to describe sects within China who are drawn to Christianity as a source of western democracy 17 . Because cultural Christians have emerged as a force of political dissent, many government officials in China remain suspicious of unregistered Christian house churches. While these Christians have a right to believe anything they would like, they do not have the freedom to disrupt social harmony. These tensions have generated crises like the one at Shouwang.

For all of these reasons, Peng's proposal for special religious zones merits risk. It is possible that such zones could become avenues through which foreign nations disrupt social harmony and loyalty to the state. If foreign political agendas are integrated into imported religious material and ultimately disrupt social harmony then the special religious zones could become a failed experiment. Alternatively, such zones could also greatly enhance social harmony.

\section{Special Religious Zones and Social Harmony}

Special religious zones in China could become 'useful opium' for the advancement of social harmony. This is not simply an outsider's perspective. In October of 2007 China's President $\mathrm{Hu}$ Jintao explicitly linked religion to social harmony, stating,

"Promoting harmony in relations between political parties, between ethnic groups, between religions, between social strata, and between our compatriots at home and overseas plays an irreplaceable role in enhancing unity and pooling strengths... We will fully implement the Party's basic principle for its work related to religious affairs and bring into play the positive role of religious personages and believers in promoting economic and social development."18

Hence, special religious zones could elicit numerous positive outcomes in China. "Many empirical studies demonstrate that, in the eyes of the majority of house church members, Christianity is not opposed to the communist party, imperialism or democracy; rather, it is only a way of

16 Michael P. Ferber. "Critical Realism and religion: objectivity and the insider / outsider problem." Annals of the Association of American Geographers. 96:1 (2006), 176-181.

17Lian Xi. "Beyond Missions."

18 FrederikFallman "Useful Opium?" 951.Originally quoted from the official English translation of Hu Jintao's speech of 15 October 2007, available 2013). 'spiritual life' and 'social life' of the believers.' 19. Examples of ways that freedom of religion might enhance social harmony could be numerous. However, two examples are especially unlikely outside of a free environment. These include Christian solutions to social crises caused by regional migration and to China's growing environmental crisis. Christians who are forced to remain in a clandestine setting are most concerned with basic aspects of the faith, as their energies are focused upon negotiating the details of underground assemblies. An experiment in special religious zones could reorient energies toward enhancing social and natural capital in China.

Special Religious Zones and Regional Migration

China is currently experiencing the largest internal migration in the world as 150 million migrant workers flock to cities from the country side. Known as "floating" workers, their population registrations remain in the country side, and so they are essentially second-class urban citizens lacking proper housing, social services and frequently fair wages for their labour.While at the Shanghai Association of Social Sciences I learned that of the 23,000,000 people in Shanghai, $9,000,000$ are among the moving population. Of these, it is impossible to know how many are religious. Starr describes the accommodation of migrant labourers as the 'thorniest' of all China's problems 20.

Migrant workers are necessary for the economy of China, in a similar way that the U.S. and Canadian economies are dependent upon immigrant labour. Yet, floating workers tend to take the first jobs they find once they move to the city.These are short term, have no job security and no benefits package.Most cannot live in regular housing and so they flock to squatter settlements on the outskirts of cities.Because they are not residents of the city they have no claim to public services.Parents cannot put their children into public schools. For instance, one migrant worker worked fourteen hours a day, seven days a week and cleared only $\$ 120$ US a month 21 . "Studies generally indicate that international migration is a complex process during which external and internal stressors will influence immigrants' mental health resulting in significant adverse clinical outcomes 22." Another major issue regarding migrant labour involves the education of the floater children, who are out of their rural jurisdictions and suffer as a result 23 .

Linked to the issue of migration is the growing gap between rich and poor in urban and rural China. The income of the richest ten percent of Chinese is sixty-five times higher on average than that of the poorest ten percent24. The gap is

19ZhaohuiHong. "Protecting and striving for the rights to religious freedom: Case studies on the Protestant house churches in China." Journal of Third World Studies.29:1.(2012), 249-261.

20 John Bryan Starr. Understanding China.

21 Ibid.

22 Jin Mou, Jinquan Cheng, Sian Griffiths, Sam Wong, Sheila Hillier, Dan Zhang. "Internal migration and depressive symptoms among migrant factory workers in Shenzhen, China."Journal of Community Psychology.39:2.(2011), 213.

23 John Bryant Starr. Understanding China.

24 Joel Brinkley. "China's Looming Crisis." World Affairs. March / April 2013, 23-31. 
forty-five times what it was in 1978, even while rural income has increased more than sevenfold since that time. Some studies demonstrate that the recent rate of disparity has decreased25, but nonetheless it represents a major problem for socialist China. China has the second largest number of billionaires and millionaires in the world, and yet $15 \%$ of the population remains in abject poverty.26A "kind of center and periphery relationship is emerging, in which poorer provinces serve as suppliers of raw material, semi-finished products, and labor power for the economic centers, which, awash in foreign capital and advanced technology, reap all the profits." 27 When the economic downturn occurred in $2008,25,000,000$ floaters could not find work in the cities and were forced to return home to their rural origins 28 .

For many migrant workers religion provides a solace for the challenges of their lives.Many Chinese are in search of a belief system to replace the Marxist / Maoist ideology of the past and the rampant consumerism of the present time. Protestant Christianity is growing rapidly among these floating workers, but it is not the only religion challenging growth thresholds in China.While at the Institute of Religious Studies in Shanghai I learned that in the city there are only seven mosques receiving Muslims from many different cultures.Because the government does not want to see religious places vacant when immigrants leave, they infrequently assign permanent space, tending to instead allocate a "temporary worship place" consisting of a three year rental agreement. Hence, most religious migrant workers are in the black and grey markets of religion in China.

A majority (70 to $80 \%$ ) of the government sanctioned Three Self Patriotic Movement(TSPM) churches are in rural areas, leaving substantial urban social needs unmet.Young people are flocking to China's cities leaving the elderly in barren rural areas and the young in overcrowded urban congregations. The spatial differentiation of wealth follows this same pattern with a wealthy urban east and a poverty-stricken rural west.A representative from the TSPM Social Services shared with us that he hopes to see more wealth within churches move in an opposite direction, but thus far such giving is limited.

Churches in urban areas have had a demonstrable effect on social services. For instance, a study in Shanghai demonstrated that "Christianity can promote social harmony in socialist China in various ways." 29 Yet, there remains a need for more urban churches to meet the social crises of growth and development in China. A recent survey of 544 Protestant believers in China by Gao found that $92.8 \%$ of those surveyed were convinced that Protestants would be able to play a key role in reconstructing the moral order in

25 Tan, L. 2012. Income Distribution in the Chinese Economy: Recent Trends and Challenges. Asian Social Science.8:1. Pgs. 3-11.

26 Joel Brinkley. "China's Looming Crisis."

27 John Bryan Starr. Understanding China, 127.

28 Ibid.

29Z. Zhan. H. Wei. C. Guo. W. Fuyou.. C. Yilun. M. Yan. L. Liang. L. Jingjing,."Functions of Protestant Churches in Promoting Social Harmony in Socialist China".Cheng Feng. 9:1. (2008), 133-174.
China.30 Many, such as Liu Peng, believe that unregistered house churches have a tremendous capacity to meet the growing social demands of China's cities, yet they remain impotent or must serve the poor in secret due to Chinese religious law. Special religious zones would open the door for more strategic and impactful social care to be provided by Christians who are currently clandestine.

Unregistered house churches provided an extraordinary response to the Sichuan earthquake. This tragic event forced the congregations to organize and find ways to collaborate and provide assistance in unison with volunteers, soldiers and commercial companies 31 . The fruit of this effort has demonstrated the capacity of unregistered churches to enhance social harmony in China as the country faces increased stress from internal migration.

Religious zones could serve as a testing ground to see how effectively religious congregations enhance social capital in Chinese communities. This is already the case with the TSPM churches where, "as an officially sanctioned part of society, Protestants are called upon to play important roles in meeting societal needs." 32

Special Religious Zones and China's Environmental Crisis

In coming decades the state of the environment in China will likely be the most pressing issue facing the nation. The extraordinary economic growth has come at a cost of air and water pollution, deforestation and nearly every form of environmental degradation imaginable. In 2006 China became the world's leading $\mathrm{CO} 2$ emitter33. Two-thirds of China's factories are polluting the air and water in violation of regulations. Nine tenths of China's cities do not meet Chinese air standards. Eighty percent of China's fresh water bodies are polluted and ninety percent of water flowing through China's cities is impotable.34By 2025 China will produce three times the amount of greenhouse gases currently produced by the United States 35 .China feeds $20 \%$ of the world's population on less than $7 \%$ of the world's arable land.Many question how China will be able to feed a growing population on a shrinking amount of arable land.Some think that by 2030 China will face a grain deficit impossible for the world's exporters to fulfill.36.

China is challenged with a double burden in that it must deal with current environmental issues while also dealing with decisions made in the past. Socialist industrialization was terribly destructive toward the environment, even more than Capitalist industrialization.Mao's attitude was that nature was an enemy to be vanquished.Additionally the

30Zhaohui Hong. "Protecting and striving."

31Chuanmei You, XunchuiChen, LanYao. "How China responded to the May 2008 earthquake during the emergency and rescue period."Journal of Public Health Policy, 30:4,(2009), 379-394.

32CarstenVala. "Protestant Christianity and Civil Society in Authoritarian China."China Perspectives.2012:3, (2012), 47.

33 Michael Kuby, Canfei He, Barbara Traspido-Lurie, Nicholas Moore.

"The Changing Structure of Energy Supply, Demand, and CO2 Emissions in

China." Annals of the Association of American Geographers.101:4. (2011).

795-805.

34 John Bryan Starr, Understanding China.

35 Michael Kubyet. al. "The changing structure of energy supply."

36 John Bryan Starr. Understanding China. 
Chinese were provided with little incentive to promote environmental stewardship. For a long time in China water and energy were supplied to consumers at no cost, or were heavily subsidized.Hence, there was absolutely no incentive to conserve.

The contemporary situation is nearly as grim. In just seven years the number of cars on China's streets increased seven-fold.China uses more coal than any other country in the world and is also the world's second largest consumer of oil, falling only behind the United States - but gaining quickly 37 . Chinese environmental laws are essentially unfunded mandates. There is no financial support to local governments to enforce environmental laws to improve the quality of air and water.Where economic development is pitted against environmental protection in China, economic development wins every time.

In 1992 the Chinese delegation to the UN Conference on Environment and Development in Rio de Janeiro was forced to admit there was no such thing as an NGO in China devoted to environmentalism. The closest comparable are the aptly named GONGOs - "Government Organized Non-Government Organizations." 38 There is currently no grassroots green movement in China, partially because the state is sensitive to groups that may be critical of the government or become political.Those groups that do emerge are local in nature and are isolated from any kind of national movement.

In such a context, the Christian Church in China could step up to voice the moral imperative of environmentalism in the country.In the United States and Canada care for the environmentamong Christians is a growing area of emphasis. Most commonly called creation care, environmental stewardship in Christian circles is also known as missionary earth keeping, eco-justice, eco missiology and evangelical environmentalism. The website of the National Religious Partnership for the Environment (NRPE), an association of independent faith groups including the Evangelical Environmental Network (EEN), the U.S. Conference of Catholic Bishops, the National Council of Churches (NCC)and the Coalition on the Environment and Jewish Life, hosts a robust collection of statements from many religious denominations and organizations39. Such statements voice denominational goals to carry out certain programs or adopt policy positions concerning ecological issues. Additionally, they help to reorient members' attention to creation care as a religious responsibility. 40

Currently in China there is virtually no emphasis on creation care or environmental stewardship in the Christian Church. During the seminar in 2011 I had many conversations with indigenous Christian leaders regarding the substantial environmental degradation in China caused in part by severe air and water pollution.In one such

37 John Bryan Starr, Understanding China.

38 Ibid.

39The National Religious Partnership for the Environment. Last accessed March 28, 2013. http://www.nrpe.org .

40 Michael P. Ferber. "American Creation Care Declarations and Initiatives."Green Education. (New York, Sage, 2011), Paul Robbins (ed.). conversation with a representative of social services in the TSPM Church at the China Christian Council I used the term "creation care" and had to subsequently define it. There was some mention made of China's significant environmental problems by the Executive Director of the Amity Foundation while we were in Shanghai.The Amity Foundation is an independent arm of the TSPM created in 1985 to help poorer areas of the country develop.It is also known as the Amity Printing Company because it is the largest Bible producer in China and, currently, in the world. While much of the support provided to Amity comes from overseas, fifty percent comes from Chinese Christians for various advocacy projects, including some limited environmental intervention. The environmental work focuses on biogas as a renewable energy source for cooking and lighting and on solar energy. Their website also emphasizes an effort to help get clean drinking water to the 200,000 Chinese who currently lack it. 41 Otherwise, the Chinese church is silent on these issues.

In a government directed study on the capacity of Christianity to enhance social harmony in China, creation care was not mentioned despite the naming of "pollution and over-exploitation of natural resources" as one of the three major problems the country must solve 42 . Water and air pollution infrequently affect only the immediate locality at the source.Provinces and regions attempting to enforce environmental regulations find that their efforts are undermined by neighbouring regions.

Chinese air and water pollution, and in particular greenhouse gas emissions, are of great importance to not only the Chinese, but the rest of the world as well.Because environmental degradation is beginning to affect economic development, there are more in China who are willing to concede.Citizens can thus play a crucial role in improving pollution regulation and controlling severe pollution 43 . The Chinese Christian Church could be on the front edge of a growing environmental movement in China and, unlike creation care in the United States, be a leader rather than a follower for advancing environmental change. The creation of special religious zones could foster an environment whereby Christians could help lead this charge.

\section{Conclusion}

This essay provided a brief overview of Liu Peng's suggestion for the CCP to consider special religious zones to open up and test freedom of religion among specific geographies within China. Special Religious Zones would be a Chinese solution to a Chinese problem, and could enhance rather than disrupt social harmony. The $\mathrm{CPC}$ has of late abandoned the classic Marxist Leninist position of opposing religion because it is an opiate, and is instead using it as an

41 Amity Foundation. Last accessed March 23, 2013. http://www.amityfoundation.org

42 Zhan et al. "Functions of Protestant Churches."

43 Benjamin Van Rooij. "The People vs. Pollution: understanding citizen action against pollution in China." Journal of Contemporary China. 19:63. (2010), 55-77 
opiate for its tendency to calm the people and advance social harmony.44 Religious zones could serve as a testing ground to see how effectively religious congregations enhance social capital in a plethora of dimensions, but in particular two current dilemmas in Chinese society are unlikely to be addressed by non-TSPM churches without freedom of religion. These include the social consequences of migrant labourers and environmental degradation. Such zones might enable religionists of all faiths, and in particular house church Christians, to fully enhance social capital without the burden of being forced to remain clandestine.

\section{Acknowledgments}

The author would like to thank the Nagel Institute and the Council of Christian Colleges and Universities for sponsoring a seminar during the summer of 2011 on religion and the rule of law in China which inspired this article.

\section{REFERENCES}

[1] T.K. Bhaurmik. Old China's New Economy: The Conquest of a Billion Paupers. (New York: Sage, 2009).

[2] Joel Brinkley. "China's Looming Crisis." World Affairs. March / April 2013, 23-31.

[3] Thomas DuBois. "Religion and the Chinese State: Three crises and a solution." Australian Journal of International Affairs. 64:3. (2010), 344-358.

[4] FrederikFallman, "Useful Opium? Adapted religion and harmony in contemporary China." Journal of Contemporary China. 19:67. (2009), 949-969.

[5] Michael P. Ferber. "American Creation Care Declarations and Initiatives."Green Education. (New York, Sage, 2011), Paul Robbins (ed.).

[6] "Critical Realism and religion: objectivity and the insider / outsider problem." Annals of the Association of American Geographers. 96:1 (2006), 176-181.

[7] Zhaohui Hong. "Protecting and striving for the rights to religious freedom: Case studies on the Protestant house churches in China." Journal of Third World Studies.29:1. (2012), 249-261.

[8] Ian. Johnson. China Gets Religion. New York Review of Books. (2011). December 22, 2011.

[9] Michael Kuby, Canfei He, Barbara Traspido-Lurie, Nicholas Moore. "The Changing Structure of Energy Supply, Demand,and CO2 Emissions in China." Annals of the Association of American Geographers. 101:4. (2011), 795-805.

[10] Tony Lambert. "Counting Christians in China: A Cautionary Report." International Bulletin of Missionary Research. 27:1 (2003), 6-10.
[11] John Micklewait and Adrian Woolridge.God is Back: How the Global Revival of Faith is Changing the World.(New York: Penguin Press, 2009).

[12] Jin Mou, Jinquan Cheng, Sian Griffiths, Sam Wong, Sheila Hillier, Dan Zhang. "Internal migration and depressive symptoms among migrant factory workers in Shenzhen, China.” Journal of Community Psychology. 39:2.(2011), 212-230.

[13] Liu Peng. Religion as a Factor in Sino-U.S. Relations. The Review of Faith and International Affairs. 6:2 (2008), 61-66.

[14] "Religious Legislation in China: Historical Evolution and Recent Developments.”Religious Studies Review. 1:1. (2007), 59-66.

[15] John Bryan Starr. Understanding China ( $3^{\text {rd }}$ edition). (2010).

[16] Bishop K. Ting. "A Call for Clarity: Fourteen Points From Christians In The People's Republic of China to Christians Abroad."China and Ourselves. 24:1. (1981).

[17] CarstenVala. "Protestant Christianity and Civil Society in Authoritarian China." China Perspectives. 2012:3, (2012).

[18] Benjamin Van Rooij. "The People vs. Pollution: understanding citizen action against pollution in China." Journal of Contemporary China. 19:63. (2010), 55-77

[19] LianXi. "Beyond Missions? Cultural Christians and Political Dissent in Contemporary China". Paper delivered at the Changing Terrains of American Protestant Missions Conference. Duke Divinity School. March 24, 2011.

[20] XiahengXie. "Religion and Modernity in China: Who Is Joining the Three-Self Church and Why". Journal of Church and State. 52:1. (2010), 74-93.

[21] Fenggang Yang. "The Red, Black and Gray Markets of Religion in China.” Sociological Quarterly. 47 (2006), 93-122.

[22] Chuanmei You, XunchuiChen, LanYao. "How China responded to the May 2008 earthquake during the emergency and rescue period." Journal of Public Health Policy, 30:4,(2009), 379-394.

[23] Z. Zhan. H. Wei. C. Guo. W. Fuyou.. C. Yilun. M. Yan. L. Liang. L. Jingjing,. "Functions of Protestant Churches in Promoting Social Harmony in Socialist China". Cheng Feng. 9:1. (2008), 133-174. 